Revta brasil. Bot., São Paulo, V.23, n.4, p.415-419, dez. 2000

\title{
Occurrence of xyloglucan containing protuberances in the storage cell walls of cotyledons of Hymenaea courbaril L.
}

\author{
MARCO AURÉLIO SILVA TINÉ ${ }^{1}$, ANGELO CORTELAZZO \\ and MARCOS S. BUCKERIDGE ${ }^{1,3}$
}

(received: Abril 12, 2000; accepted: August 2, 2000)

\begin{abstract}
Occurrence of xyloglucan containing protuberances in the storage cell walls of cotyledons of Hymenaea courbaril L.). Despite the suggestions of its pectic composition, no clear evidence for this has been presented. Here we show the occurrence of such a structure in walls of cells from cotyledons of Hymenaea courbariI L. These cells are known to accumulate large amounts of storage xyloglucan in the wall and, in this case, the protuberances seem to contain this storage polysaccharide rather than pectin. A hypothetical sequence of events leading from wall strands to protuberances was assembled based on scanning electron microscopy observations. On this basis, a tentative model for how polysaccharides are distributed into the wall, near the regions where protuberances are found, is proposed to explain the presence of storage xyloglucan in their composition.
\end{abstract}

RESUMO - (Ocorrência de protuberâncias contendo xiloglucano nas paredes celulares da reserva de Hymenaea courbaril L.). Apesar das sugestões da sua composição péctica, não foram apresentadas evidências diretas da sua composição. Neste trabalho é mostrada a ocorrência desta estrutura em paredes de células parenquimáticas de cotilédones de Hymenaea courbaril L. Sabe-se que estas células acumulam grandes quantidades de xiloglucano nas suas paredes e, nesse caso, as protuberâncias parecem conter este polissacarídeo na sua constituição. Uma sequiência de eventos que leva ao aparecimento destas protuberâncias é sugerida e um modelo de parede celular é proposto para explicar a presença de xiloglucano de reserva na composição das protuberâncias.

Key words - Xyloglucan, pectin, cell wall, protuberances, Hymenaea courbaril

\section{Introduction}

The plant cell wall is a composite formed by three different matrices (cellulose/hemicellulose, pectin and protein) that coexist independently. In the plant tissues, cells are cemented together by pectic polysaccharides forming a structure named middle lamella (Roland et al. 1992, Carpita \& Gibeaut 1993). Whereas the cellulose/hemicellulose matrix is assumed to be responsible for the mechanical strength of the wall, the structural protein matrix is usually associated with wall loosening. In some seeds, the deposition of one of these matrices is proportionally increased, generating a great deposit of carbohydrate which functions as a storage compound.

During the formation of certain tissues, the cell wall develops structures known as Intercellular Pec-

1. Seção de Fisiologia e Bioquímica de Plantas, Instituto de Botânica, Caixa Postal 4005, CEP 01061-970 São Paulo, SP, Brasil.

2. Depto. de Biologia Celular e Morfologia, Instituto de Biologia, UNICAMP, Campinas, SP, Brasil.

3. Corresponding author: msbuck@usp.br tic Protuberances (IPP) (Potgieter \& van Wyk 1992). According to these authors, IPPs are thought to be associated with the formation of intercellular spaces during tissue expansion. IPPs are widespread throughout the plant kingdom from ferns to angiosperms (Carr et al. 1980b, Potgieter \& van Wyk 1992). Largely ignored in anatomy books, their function is not clear yet. Among the proposed functions, cell adhesion, cell wall hydration and apoplastic transport have been proposed. They were first reported in the $19^{\text {th }}$ century (see Potgieter \& van Wyk 1992 for a review), but their composition has not been defined exactly yet. Although a pectic composition has been proposed by some authors (Carr \& Carr 1975, Carr et al. 1980a and b, Machado \& Sajo 1996), a complex composition has been proposed by others (Butterfield et al. 1981). Being part of the plant cell wall, it is reasonable to suppose that different cell wall polysaccharides might be present.

Here, we report the occurrence of protuberances in the storage cell walls of cotyledons of Hymenaea courbaril. These walls are known to accumulate xyloglucan, which is also named "amyloid" due to its characteristic blue colour when impregnated with iodine. In the protuberances of walls of $H$. courbaril, 
xyloglucan has been detected with iodine whereas no pectin was detected with toluidine blue.

\section{Material and methods}

Seeds of Hymenaea courbaril L. were provided by the Seed Department of the Institute of Botany at São Paulo (Brazil). The seeds were scarified individually, soaked in tap water overnight and planted in vermiculite. The pots were kept at $25^{\circ} \mathrm{C}$ under a photoperiod of $12 \mathrm{~h}$ for 40 days and cotyledons were collected for microscopic analyses.

Mesophyll tissues from cotyledons were dissected in order to produce cuboid blocks measuring approximately $5 \mathrm{~mm}$ length at all sides. The blocks were fixed with $p$-formaldehyde (4\%) /glutaraldehyde (2.5\%) in phosphate buffer $0.1 \mathrm{M} \mathrm{pH} 7.4$ for 24 $\mathrm{h}$ at $5{ }^{\circ} \mathrm{C}$, washed in the same buffer, dehydrated in a series of ethanol (70, 80, 95, 100\%, successively) at room temperature, included in Paraplast and $8 \mu \mathrm{m}$ sections were obtained (Kierman 1981). For iodine impregnation, the sections were covered with a solution of $\mathrm{I}_{2} / \mathrm{KI}(0.5 \% / 1 \%)$ and photographed immediately. For neutral carbohydrate staining, periodic acid-Schiff (PAS) method was used according to Cortelazzo (1992). For total anionic radicals, toluidine blue was used according to Vidal (1977).

For Scanning Electron Microscopy (SEM), pieces of cotyledons were mounted on stubs, freeze-dried, coated with gold (Baltec SCD 050 coater), examined, and photographed in a Philips Scanning Electron Microscope XL20 at an acceleration voltage of $10 \mathrm{kV}$.

\section{Results and Discussion}

Cell wall protuberances were observed in the intercellular spaces of the storage parenchyma from seeds of Hymenaea courbaril (figures 1-5). The analysis by scanning electron microscopy showed that when tissue was broken, cells broke preferentially at the pit fields (asterisk in figure 1). It is clear in this picture that protuberances are present in the intercellular spaces (white arrows in figure 1) and not related with the pit field structure.

Cytochemical analysis using light microscopy, showed that the protuberances stain in red with PAS, indicating that it contains neutral sugars. On the other hand, they also stained in blue with iodine (figures 3,5), suggesting the presence of storage xyloglucan in their composition. The lack of colour when stained with toluidine blue (a dye that interacts with anionic radicals), indicates that little or no acid polysaccharides are present in their composition (figure 4).

Altogether, these results suggest that the protuberances visualised in cotyledon cells of Hymenaea courbaril are composed mostly of xyloglucan and either lack or contain very little pectin.

A close examination using SEM revealed that besides protuberances, certain regions present strand-like structures (open arrow in figures 1, 6 and 7), these regions being the ones in which intercellular contact is still present. A careful search under the SEM allowed the visualisation of different stages of the process of strand breaking into protuberances. These were assembled in figure 2 .

The fact that strands are present where storage walls are in close contact with each other is consistent with the proposed origin of these protuberances (Potgieter \& van Wyk 1992). Some parts of walls of contiguous cells would remain linked to each other after the separation of the cells following imbibition. These regions would form strands of wall material between the cells that would eventually break and form the protuberances observed (figures 8 and 9).

Based on the current models of the primary cell walls (Carpita and Gibeaut 1993) and of storage cell walls (Buckeridge et al. 2000) a possible explanation for the existence of such strands of storage xyloglucan could be thought as hemicellulosic "bridges" which would have to cross the primary cell wall. One possibility is pictured in figure 10. In this picture, the middle lamella is drawn as discontinuous and storage material is crossing from one storage wall to the other. No transmission electron microscopy has been reported for $H$. courbaril yet, but in another species that accumulate xyloglucan (Tropaeolum majus) the middle lamella presented cross reaction with a xyloglucan-specific probe (gold particles covered with endo- $\beta$-glucanase nowadays named xyloglucan endo-transglycosilase - see figure 8 in Vian et al. 1991).

Several possible functions for these protuberances have been suggested such as cell wall hydration, storage, cell adhesion, defence and apoplastic transport, but none have been confirmed beyond doubt (Potgieter \& van Wyk 1992). Besides these functions, in the case of the cotyledons of $H$. courbaril, the strands may be related to maintenance of tissue integrity during imbibition and cell expansion prior to xyloglucan mobilisation. If the storage cell wall have the architecture proposed in figure 10, 

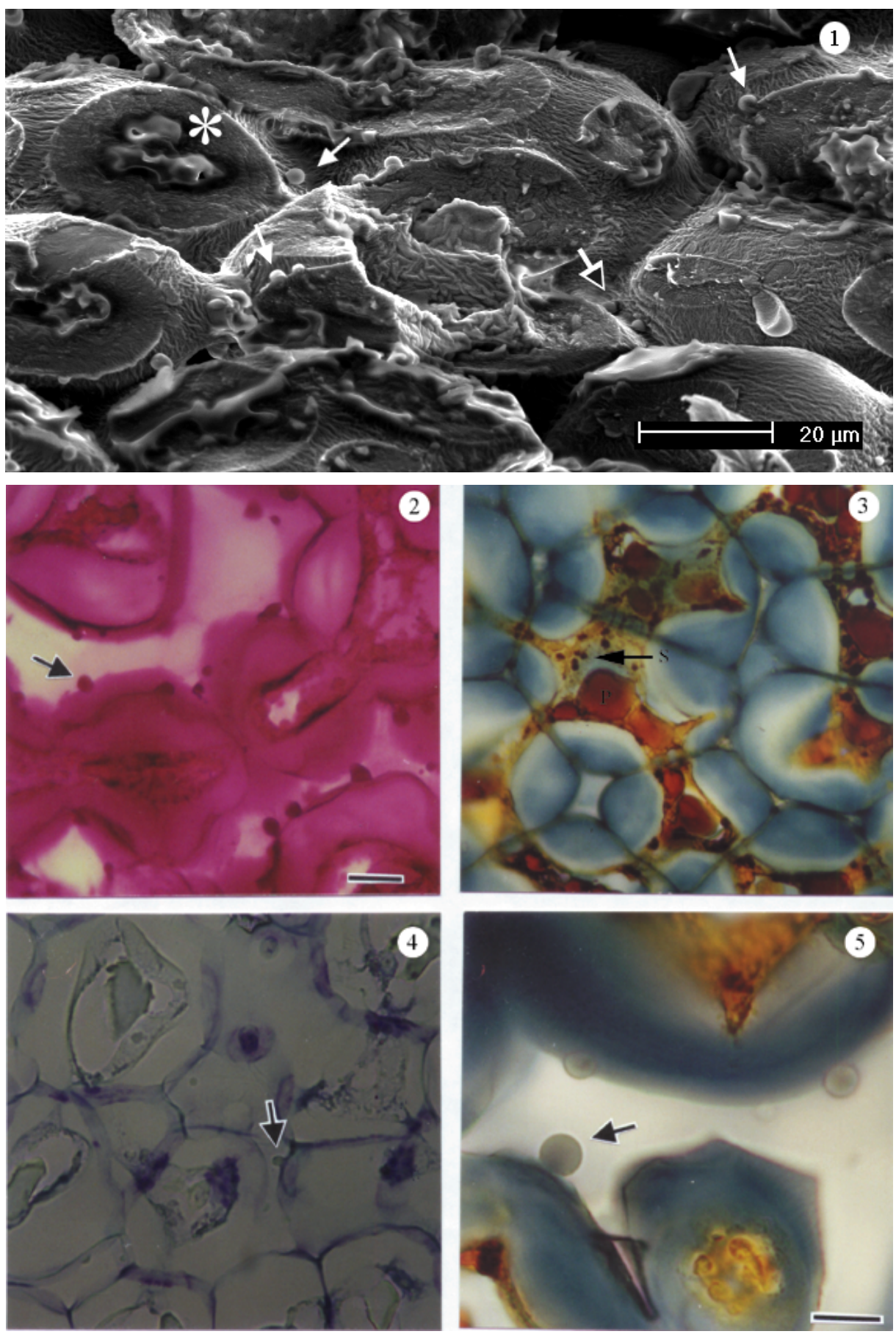

Figures 1-5. Scanning electron microscopy and light microscopy of transversal sections of storage parenchyma of cotyledons of Hymenaea courbaril . 1. scanning electron micrography showing protuberances (white arrows) and strand (open arrow) on the surface of cotyledon cells. Pit fields are indicated (*). 2. staining for neutral polysaccharides (PAS) showing storage wall xyloglucan with protuberances (arrow). 3. iodine impregnation showing storage cell walls in blue, protein bodies $(\mathrm{P})$ and starch granules $(\mathrm{S})$. 4. staining for acidic polysaccharides of the wall (pectins in purple). Protuberances do not stain (arrow). 5. impregnation with iodine of protuberances on the surface of storage walls (arrow). Bars in 2-4 $=20 \mu \mathrm{m}$ and in $5=10 \mu \mathrm{m}$. 

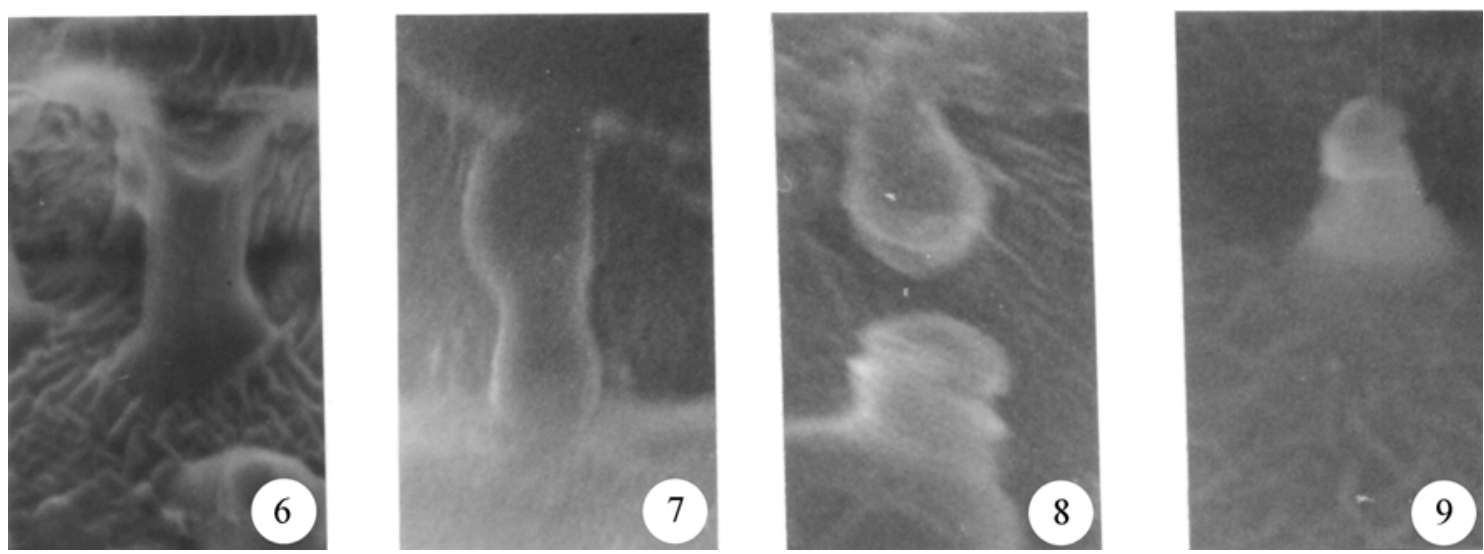

Figures 6-9. Proposed mechanism for the formation of protuberances on the surface of the storage cell walls of cotyledons from Hymenaea courbaril assembled from different micrographies. During expansion caused by water imbibition, cells are pulled apart so that xyloglucan-containing strands (6) become under tension (7) and eventually break (8) into protuberances (9). $1 \mathrm{~cm}$ corresponds to approximately $1 \mu \mathrm{m}$.

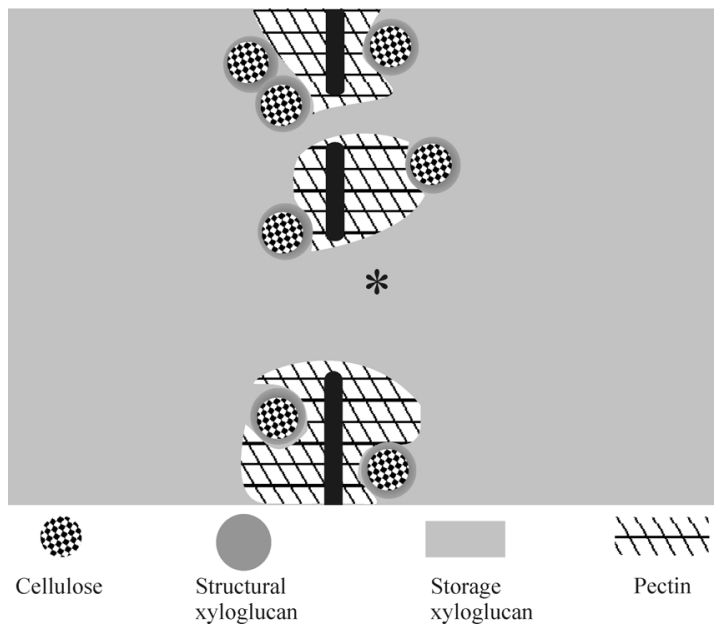

Figure 10. Tentative model for the cell wall of storage cells of Hymenae courbaril cotyledons with interruptions in the primary wall with storage xyloglucan. These "bridges" (*) of xyloglucan in the primary cell wall would become strands and subsequently protuberances of xyloglucan upon the separation of the cells.

these xyloglucan "bridges" might also be important in the transport of solutes or water between contiguous cells.

Acknowledgements - The authors are indebted with Mary Anne Heidi Dolder and Henrique Pessoa dos Santos for the help with the SEM. M.A.S. Tiné and M.S. Buckeridge thank help by CNPq for fellowship funding. This work has been funded by BIOTAFAPESP (98/05124-8).

\section{References}

BUCKERIDGE, M.S., SANTOS, H.P. \& TINÉ, M.A.S. 2000. Mobilization of storage cell wall polysaccharides in seeds. Plant Physiology and Biochemistry 38:141-156.

BUTTERFIELD, B.G., MEYLAN, B.A. \& EXLEY, R.R. 1981. Intercellular protuberances in the ground tissue of Cocos nucifera L. Protoplasma 107:69-78.

CARPITA, N.C. \& GIBEAUT, D.M. 1993. Structural models of primary cell walls in flowering plants: consistency of molecular structure with the physical properties of the cell wall during growth. The Plant Journal 3:1-30.

CARR, S.G.M. \& CARR, D.J. 1975. Intercellular pectic strands in parenchyma: studies of plant cell walls by scanning electron microscopy. Australian Journal of Botany 23:95-105.

CARR, D.J., CARR, S.G.M. \& JAHNE, R. 1980a. Intercellular strands associated with stomata: stomatal pectic strands. Protoplasma 102:177-182.

CARR, D.J., OATES, K. \& CARR, S.G.M. 1980b. Studies on intercellular pectic strands of leaf palisade parenchyma. Annals of Botany 45:403-413.

CORTELAZZO, A.L. 1992. Detecção e quantificação do amido em cotilédones de Canavalia ensiformis e C. gladiata durante o desenvolvimento inicial da planta. Revista Brasileira de Botânica 15:157-162.

KIERMAN, J.A. 1981. Histological and histochemical methods. Theory and practice. Pergamon Press, London.

MACHADO, S.R. \& SAJO, M.G. 1996. Intercellular pectic protuberances in leaves of some Xyris species (Xyridaceae). Canadian Journal of Botany 74:1539-1541. 
POTGIETER, M.J. \& VAN WYK, A.E. 1992. Intercellular pectic protuberances in plants: their structure and taxonomic significance. Botanical Bulletin of Academia Sinica 33:295-316.

ROLAND, J.C., REIS, D. \& VIAN, B. 1992. Liquid crystal order and turbulence in the planar twist of the growing plant cell walls. Tissue and Cell 24:335-345.
VIAN, B., NAIRN, J. \& REID, J.S.G. 1991. Enzyme-gold cytochemistry of seed xyloglucans using two xyloglucan-specific hydrolases. Importance of prior heat-deactivation of the enzymes. Histochemical Journal 23:116-124.

VIDAL, B.C. 1977. Acid glycosaminoglycans and endochondrial ossification. Cell Molecular Biology 22:45-64. 